\title{
Up-regulation of rat myometrial phospholipases $C \beta 1$ and $C \beta 3$ correlates with increased term sensitivity to carbachol and oxytocin
}

\author{
E Houdeau', A Lévy and S Mhaouty-Kodja \\ Laboratoire de Physiologie et Physiopathologie, UMR-CNRS 7079, Paris cedex 05, France \\ ${ }^{1}$ Unité de Neuro-Gastroentérologie et Nutrition, INRA, 31931 Toulouse cedex 9, France \\ (Requests for offprints should be addressed to S Mhaouty-Kodja, UMR-CNRS 7148, Collège de France, 11 place Marcelin Berthelot, 75231 Paris cedex 05, \\ France; Email: sakina.mhaouty-kodja@college-de-france.fr)
}

\begin{abstract}
In the present study, we compared rat uterine contractility and myometrial inositol phosphate (InsP) production in response to activation of muscarinic and oxytocin receptors during pregnancy and at term. The level of myometrial phospholipase (PL) C $\beta$ was also determined by Western blotting at different stages of pregnancy and following administration of oestradiol, progesterone or vehicle. The results showed an increased potency of carbachol $(\mathrm{CCh})$, a cholinergic muscarinic agonist, and oxytocin (OT) to enhance myometrial InsP production at term. This correlated with an increased potency of both agonists to induce contraction of the circular but not the longitudinal muscle. For both InsP production and contractile activity, the maximal response of $\mathrm{CCh}$ was unaltered, while that of OT was significantly increased. Interestingly, the increased
\end{abstract}

responsiveness to $\mathrm{CCh}$ and $\mathrm{OT}$ was associated with an up-regulation of PLC $\beta 1$ and PLC $\beta 3$ enzymes. Such regulation is under the control of oestradiol since administration of this steroid to pregnant rats increased the amount of both enzymes by 200-260\%. In contrast, progesterone administration was without effect. The present study presents the first evidence that the expression of rat myometrial PLC $\beta 1$ and PLC $\beta 3$ is under the positive control of oestradiol. This could participate in the enhancement of myometrial InsP accumulation and uterine contraction at term in response to CCh and OT. Based on contraction studies, we also propose that the longitudinal and circular uterine muscles differ in the regulation of the PLC pathway during pregnancy.

Journal of Endocrinology (2005) 187, 197-204

\section{Introduction}

Phospholipase (PL) C, by hydrolyzing the membrane phosphatidylinositol 4,5-biphosphate into diacylglycerol and inositol 1,4,5-triphosphate $\left(\operatorname{Ins}_{3}\right)$, increase $\operatorname{InsP}_{3}-$ dependent liberation of $\mathrm{Ca}^{2+}$ from intracellular stores. The subsequent activation of myosin light chain kinase promotes the interaction between actin and myosin, thereby resulting in contraction. Among the large PLC family (11 genes), the four members of the PLC $\beta$ subfamily (PLC $\beta 1$, PLC $\beta 2$, PLC $\beta 3$ and PLC $\beta 4$ ) are activated by G proteincoupled receptors. PLC $\beta 1$ and PLC $\beta 4$ are only activated by the Gq $\alpha$ subunit whereas PLC $\beta 2$ and PLC $\beta 3$ are also sensitive to the $G \beta \gamma$ complex (Rebecchi \& Pentyala 2000).

The PLC signalling pathway plays an important role in the regulation of uterine contractility. Indeed, contractant factors like oxytocin $(\mathrm{OT})$, prostaglandins or norepinephrine utilize PLC-coupled receptors (OT receptors (OTR), prostaglandin F2 $\alpha$ receptors (FP) and $\alpha 1$ adrenergic receptors (AR) respectively) to increase intracellular concentrations of $\mathrm{Ca}^{2+}$.
During pregnancy, these signalling pathways are silent due to the negative control exerted by progesterone. For instance, progesterone inhibits the expression of OTR and FP (Larcher et al. 1995, Ou et al. 2000). Progesterone can also indirectly modulate the PLC signalling pathway by enhancing the expression of $\beta-A R$ and their cognate Gsa protein (Vivat et al. 1992, Elwardy-Mérézak et al. 1994). It has been shown that the subsequently produced cAMP reduces myometrial inositol phosphate (InsP) production through phosphorylation of PLC $\beta$ by protein kinase A in the rat (Dodge et al. 1999). Activation of rat myometrial $\beta$-AR was also reported to reduce basal and agonist-stimulated InsP production during pregnancy through a cAMP-independent mechanism involving $\mathrm{K}^{+}$ channels (Khac et al. 1996, Mhaouty-Kodja et al. 2004). At term, the concomitant progesterone withdrawal and increase of oestradiol concentrations are thought to promote transcriptional activation of OTR and FP (Larcher et al. 1995, Ou et al. 2000). This results in enhanced phosphoinositide hydrolysis and uterine responsiveness to OT and prostaglandins (Goureau et al. 1992, Dodge et al. 1999). 
Acetylcholine released from uterine parasympathetic nerves was also described to regulate rat uterine contractility through activation of muscarinic receptors ( $\mathrm{mRs}$ ) (Houdeau et al. 2003). However, its role in the initiation of labour still remains a controversial question. Indeed, while some studies reported a declined sensitivity and maximal response to the muscarinic agonist carbachol (CCh) (Riemer et al. 1986), others have described an enhanced CCh-mediated generation of myometrial InsP at the end of pregnancy (Lajat et al. 1996). Characterization of myometrial $\mathrm{mR}$ revealed the presence of $\mathrm{M}_{2}$ and $\mathrm{M}_{3}$ receptor subtypes that couple to adenylyl cyclase and PLC respectively (Lajat et al. 1996, Choppin et al. 1999). In contrast to the PLC-coupled receptors described above, no detectable changes in the density and properties of the $\mathrm{M}_{3}$ receptor were observed during the course of pregnancy (Lajat et al. 1996). In correlation with these data, oestradiol treatment did not affect the expression of $\mathrm{M}_{3}$ receptor in rat myometrial cells (Abdalla et al. 2004). However, we have previously shown that the expression of $\mathrm{Gq} \alpha$, the transducer protein that links $\mathrm{mR}$ and OTR to PLC $\beta$, increases at the end of pregnancy (CohenTannoudji et al. 1995). Furthermore, we recently described an up-regulation of rat myometrial PLC $\beta 1$ and PLCß3 at term (Mhaouty-Kodja et al. 2004).

In the light of these findings, the present study was designed to evaluate the effect of CCh on myometrial InsP production and uterine contractile activity in pregnant and term rats. Uterine responses to OT, which utilizes the same signal pathway as $\mathrm{mR}$ to induce uterine contraction, were also determined. Finally, the effects of oestradiol and progesterone on the expression of rat myometrial PLC $\beta 1$ and PLC $\beta 3$ were evaluated.

\section{Materials and Methods}

\section{Animals and treatments}

Sprague-Dawley rats were obtained from Janvier (Le Genest, France). The females were caged with males overnight and successful mating was determined by the presence of spermatozoa in the vaginal smear (day 1 of pregnancy). Animals were killed by cervical dislocation on days $12,15,16$ and 21 of pregnancy or at term during the expulsion of fetoplacental units, in accordance with the guidelines for the care and use of laboratory animals (NIH Guide). The uterine horns were quickly isolated, cut open lengthwise and the fetoplacental units removed. The myometrium was then freed of adherent endometrium except for uterine tension studies.

Oestradiol-treated animals received subcutaneous injections of $0.5 \mathrm{ml}$ olive oil containing $6 \mathrm{mg}$ oestradiol (Sigma, L'isle d'Abeau, France) at 1000 and $1600 \mathrm{~h}$ on day 15 of pregnancy and were killed by cervical dislocation at $1000 \mathrm{~h}$ the following day (day 16). Progesterone-treated rats received subcutaneous injections of $0.5 \mathrm{ml}$ olive oil containing $5 \mathrm{mg}$ progesterone (Sigma) on day 21 of pregnancy $(1000 \mathrm{~h})$ and were killed by cervical dislocation $30 \mathrm{~h}$ after injection (day 22). Control rats received the same volume of oil subcutaneously on the same schedule. The doses of progesterone and oestradiol administered significantly increased the myometrial levels of both steroids as we have determined in previous works (ElwardyMérézak et al. 1994, Cohen-Tannoudji et al. 1995).

\section{Isometric tension measurement}

Four millimetre long uterine strips were prepared from pregnant rats and mounted in organ baths containing $8 \mathrm{ml}$ Krebs solution $(144 \mathrm{mM} \mathrm{NaCl}, 6.2 \mathrm{mM} \mathrm{KCl}, 0.5 \mathrm{mM}$ $\mathrm{MgSO}_{4}, 1 \mathrm{mM} \mathrm{NaH} \mathrm{PO}_{4}, 30 \mathrm{mM} \mathrm{NaHCO}, 2.5 \mathrm{mM}$ $\mathrm{CaCl}_{2}$ and $2 \cdot 8 \mathrm{mM}$ glucose, $\mathrm{pH} 7 \cdot 4$ ) bubbled with $95 \%$ $\mathrm{O}_{2} / 5 \% \mathrm{CO}_{2}$ and warmed to $30^{\circ} \mathrm{C}$. Depending on the orientation of the uterine strips in the organ bath, we measured isometric contractions of longitudinal muscle or circular muscle using a Bioscience UF1 tension transducer (Phymep, Paris, France) under $0.7 \mathrm{~g}$ resting force. A 30-min equilibration period was allowed before adding cumulative doses of $\mathrm{CCh}$ or OT $(0.1 \mathrm{nM}$ to $1 \mathrm{mM}$; Sigma). The concentration-response curves were recorded by computerized calculation of the integral under the tension/time curve for $3 \mathrm{~min}$ using Prism 4 software (Graph Pad, San Diego, CA, USA) for sigmoidal doseresponse (non-linear regression fit). Isometric changes in tissue tension and maximal effects $\left(\mathrm{E}_{\max }\right)$ are expressed as a percentage above the spontaneous activity in the absence of agonists, and potency as $\mathrm{EC}_{50}$.

\section{Myometrial InsP production}

InsP production was measured as previously described (Mhaouty-Kodja et al. 2001). Myometrial strips were incubated at $37^{\circ} \mathrm{C}$ for $4 \mathrm{~h}$ with $7 \mu \mathrm{Ci}$ myo- $\left[{ }^{3} \mathrm{H}\right]$ inositol (10-25 Ci/mmol; Perkin Elmer Life Sciences, Paris, France) in $1 \mathrm{ml}$ Krebs bicarbonate buffer $(117 \mathrm{mM} \mathrm{NaCl}$, $4.7 \mathrm{mM} \mathrm{KCl}, 1.1 \mathrm{mM} \quad \mathrm{MgSO}_{4}, 1.2 \mathrm{mM} \mathrm{KH}_{2} \mathrm{PO}_{4}$, $24 \mathrm{mM} \mathrm{NaHCO} 3,0.8 \mathrm{mM} \mathrm{CaCl} 2$ and $1 \mathrm{mM}$ glucose, $\mathrm{pH} 7 \cdot 4)$ in the presence of $95 \% \mathrm{O}_{2} / 5 \% \mathrm{CO}_{2}$. Increasing concentrations of CCh or OT $(0 \cdot 1 \mathrm{nM}$ to $100 \mu \mathrm{M})$ were added after 10-min incubation of myometrial strips with $10 \mathrm{mM} \mathrm{LiCl}$ (Sigma) in Krebs bicarbonate buffer. Assays were stopped $15 \mathrm{~min}$ later by freezing the strips in liquid $\mathrm{N}_{2}$.

Strips were homogenized in 7\% trichloroacetic acid and the supernatant obtained was extracted with diethyl ether, neutralized with Tris-base and then chromatographed over anion-exchange resin (AG1-X8; Bio-Rad Laboratories, Marnes-la-Coquette, France). Total InsP eluted with $1 \mathrm{M}$ ammonium formate $/ 0 \cdot 1 \mathrm{M}$ formic acid was counted by liquid scintillation in a 1214 Rack-beta spectrometer (LKB, Turku, Finland) for tritium. 


\section{Western blot analysis}

Rat myometrium was homogenized in $0.5 \mathrm{mM}$ EDTA and $10 \mathrm{mM}$ Tris $\mathrm{pH} 7 \cdot 4$ supplemented with a cocktail of protease inhibitors (Sigma). After centrifugation at $4{ }^{\circ} \mathrm{C}$, supernatants were collected and submitted to $100000 \mathrm{~g}$ centrifugation at $4{ }^{\circ} \mathrm{C}$ for $1 \mathrm{~h}$ to separate plasma membranes from cytosol. Protein concentration of cytosolic fraction was determined according to Bradford (1976) with bovine serum albumin as standard. Samples were stored at $-80{ }^{\circ} \mathrm{C}$ until use.

Twenty micrograms of proteins were subjected to SDS-PAGE in $7 \cdot 5 \%$ gels and transferred to polyvinylidene difluoride membranes (Perkin Elmer Life Sciences). The blots were blocked overnight at $4{ }^{\circ} \mathrm{C}$ in Tris-buffered saline containing $5 \%$ non-fat dried milk, and incubated for $1 \mathrm{~h}$ at room temperature with polyclonal anti-PLC $\beta$ (Santa Cruz Biotechnology, Santa Cruz, CA, USA) diluted 1:500. Incubation with peroxidase-conjugated goat antirabbit antibody (Jackson ImmunoResearch, West Grove, PA, USA) diluted 1:10 000 was carried out for $45 \mathrm{~min}$ at room temperature. Immunoreactive bands were visualized by the chemiluminescence detection system (Amersham Pharmacia Biotech, Les Ulis, France) and quantified. The quantification of PLC $\beta$ expression was determined by densitometric scanning followed by computer analysis using the NIH image 1.62 program.

\section{Statistical analysis}

Results are expressed as means \pm S.E.M. Statistical significance was assessed by Student's $t$-test for unpaired data. $P$ values less than $0 \cdot 05$ were considered significant.

\section{Results}

Uterine contraction in response to CCh and OT in pregnant and term rats

We compared rat uterine activity in response to $\mathrm{CCh}$ and OT on day 15 of pregnancy and at term. For this, we measured isometric contractions of the longitudinal and circular muscles depending on the orientation of the uterine strips in the organ bath as described in Materials and Methods. All uterine strips exhibited spontaneous rhythmic contractions a few minutes after being mounted in the bath (data not shown). Addition of increasing concentrations of $\mathrm{CCh}$ or OT dose dependently enhanced the activity of the circular and longitudinal uterine muscles (Figs 1 and 2). This indicated the presence of functional $\mathrm{mRs}$ and OTRs in both myometrial layers during pregnancy and at term. In the circular muscle, $\mathrm{EC}_{50}$ values for $\mathrm{CCh}$ and OT were respectively sevenfold and sixfold decreased at term when compared with day 15 of pregnancy, indicating that both agonists were more potent at inducing contraction at term $(P<0 \cdot 05$; Fig. $2 a$ and $b$ and Table 1). The $\mathrm{E}_{\max }$ to $\mathrm{CCh}$ was not significantly different (a)

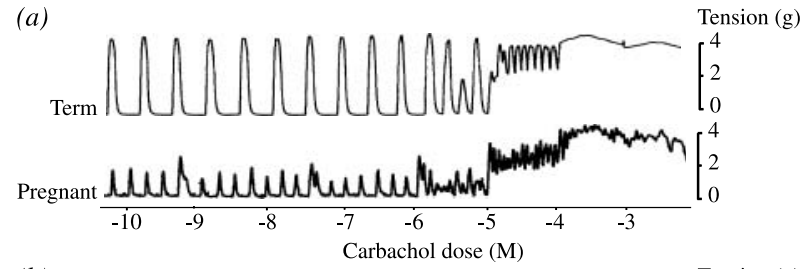

(b)
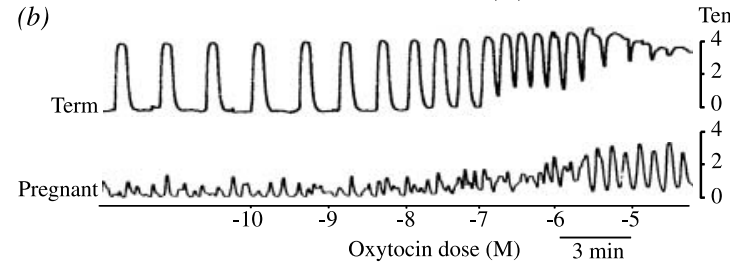

Figure 1 Representative recordings of uterine tension of the circular muscle in response to increasing doses of (a) CCh and (b) OT on day 15 of pregnancy and at term.

between pregnant and term rats (Fig. 2a) whereas that of OT was increased by $100 \%$ at term $(P<0 \cdot 05$; Fig. $2 b)$. In the longitudinal muscle, no major changes in the potency and maximal response of $\mathrm{CCh}$ were observed between day 15 of pregnancy and term (Fig. $2 c$ and Table 1). For OT, a significant increase in the $\mathrm{E}_{\max }$ was seen only at $1 \mu \mathrm{M}$
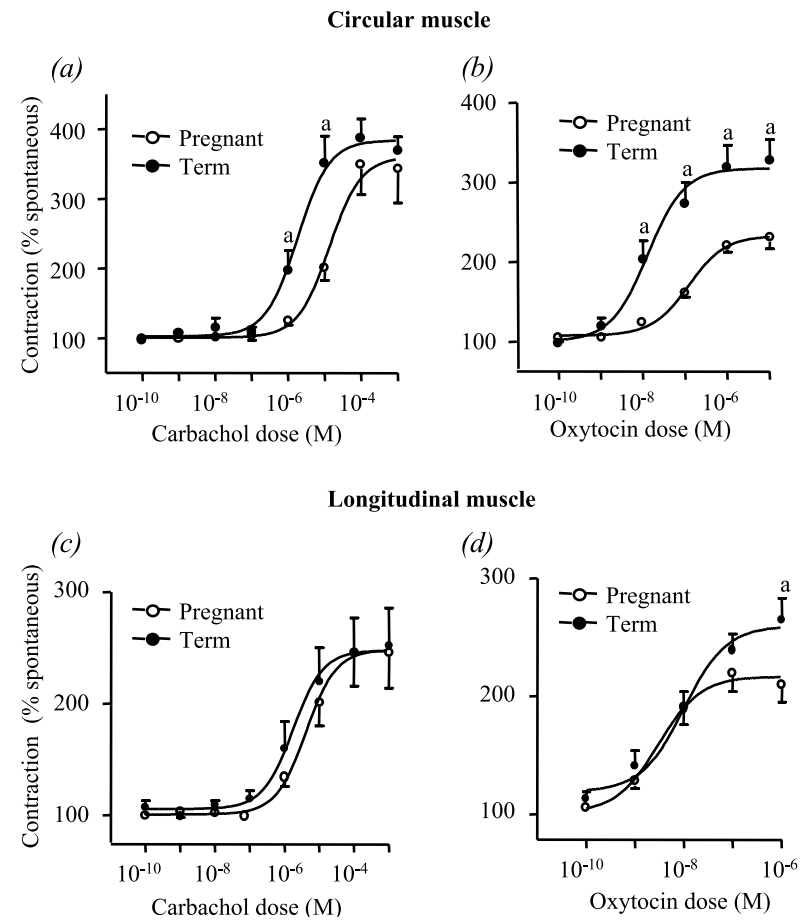

Figure 2 Contractile activity of the ( $a$ and $b$ ) circular and (c and $d$ ) longitudinal muscles of rat uterus on day 15 of pregnancy and at term in response to increasing concentrations of ( $a$ and $c$ ) CCh and $(b$ and $d)$ OT. Results are expressed as percent of spontaneous contraction and are means \pm S.E.M. of six to eight independent experiments. ${ }^{a} P<0.05$ versus the same concentration on day 15 of pregnancy. 
Table $1 \mathrm{EC}_{50}$ values for contractile activity of the circular and longitudinal muscles and myometrial InsP production elicited by CCh and OT on day 15 of pregnancy and at term. Values are means \pm S.E.M. $(n=4-8)$

\begin{tabular}{|c|c|c|c|c|}
\hline & \multicolumn{2}{|l|}{ CCh $(\mu \mathrm{M})$} & \multicolumn{2}{|l|}{ OT (nM) } \\
\hline & Day 15 & Term & Day 15 & Term \\
\hline \multicolumn{5}{|l|}{ Contraction } \\
\hline Circular muscle & $20 \pm 5$ & $3 \pm 0 \cdot 9^{a}$ & $114 \pm 30$ & $20 \pm 6^{a}$ \\
\hline Longitudinal muscle & $2 \cdot 6 \pm 0 \cdot 3$ & $1 \cdot 5 \pm 0 \cdot 5$ & $3 \pm 0 \cdot 6$ & $8 \pm 2^{\mathrm{a}}$ \\
\hline InsP production & $2 \cdot 3 \pm 0 \cdot 9$ & $0 \cdot 004 \pm 0 \cdot 001^{\mathrm{a}}$ & $3 \cdot 6 \pm 0 \cdot 9$ & $1 \cdot 5 \pm 0 \cdot 25^{a}$ \\
\hline
\end{tabular}

concentration $(P<0 \cdot 05$; Fig. $2 d)$ while a twofold decrease of the $\mathrm{EC}_{50}$ occurred at term $(P<0 \cdot 05$; Table 1$)$.

The responsiveness of the circular muscle to $\mathrm{CCh}$ and OT was therefore increased at term. To assess whether this correlates with changes in $\mathrm{mR}$ and OTR signalling pathways, we compared myometrial Ins $\mathrm{P}$ responses to $\mathrm{CCh}$ and OT between day 15 of pregnancy and term.

\section{Basal and agonist-stimulated InsP production in pregnant and} term rat myometrium

We incubated myometrial strips from pregnant and term rats in the absence or presence of increasing concentrations of $\mathrm{CCh}$ or OT. At term, basal InsP production was augmented by $72 \%$ (9325 \pm 351 c.p.m./100 mg tissue on day 15 of pregnancy versus $16053 \pm 812$ c.p.m./100 mg tissue at term; $P<0.0001)$. In order to evaluate the net responses due to the specific activation of $m R s$ or OTRs, agonist-stimulated Ins $\mathrm{P}$ production was therefore expressed as percent of basal. Results illustrated in Fig. 3 show that $\mathrm{CCh}$ and $\mathrm{OT}$ increased InsP production dose dependently on both day 15 of pregnancy and at term. The $\mathrm{EC}_{50}$ values for both agonists were significantly lower at term when compared with day $15(P<0 \cdot 05$; Table 1$)$ as evidenced by the leftward shift in the dose-response curves (Fig. 3). The $\mathrm{E}_{\max }$ for $\mathrm{CCh}$ was unaltered at term while a $50 \%$ increase occurred for OT $(P<0 \cdot 05$; Fig. 3$)$. It
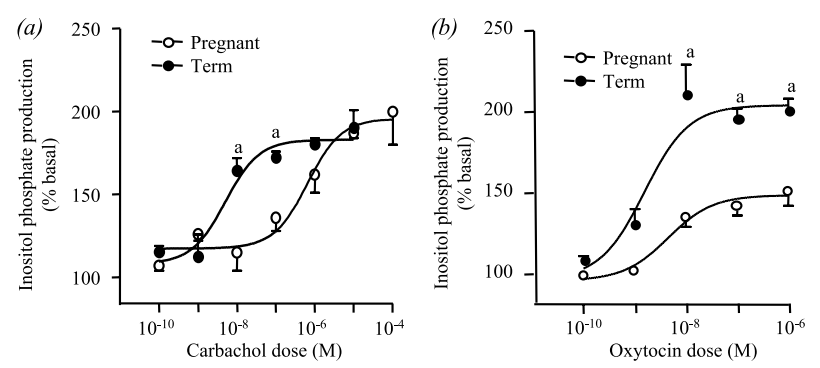

Figure 3 InsP production of myometrial strips from rats on day 15 of pregnancy and at term in response to (a) CCh and (b) OT. Results are expressed as percent of basal InsP production and are means \pm S.E.M. of four to five independent experiments. ${ }^{a} P<0 \cdot 05$ versus the same concentration on day 15 of pregnancy. is therefore interesting to note that total myometrial InsP responses correlated well with contractile activity of the circular muscle, thereby suggesting that the important changes in $\mathrm{CCh}$ and $\mathrm{OT}$ responses between pregnancy and term occur in this muscle layer.

\section{Quantification of rat myometrial PLC $\beta 1$ and PLC $\beta 3$ during pregnancy}

In contrast to OTR, the density of myometrial PLCcoupled $\mathrm{M}_{3}$ receptor is unchanged during the course of pregnancy in the rat (Lajat et al. 1996). The increased uterine sensitivity to $\mathrm{CCh}$ might thus be related to changes occurring downstream of $\mathrm{mRs}$. We recently showed that the amount of myometrial PLC $\beta 1$ and PLC $\beta 3$ is greatly increased in term rats versus day 15 of pregnancy (Mhaouty-Kodja et al. 2004). Interestingly, the level of their cognate Gqa protein is also increased at the end of pregnancy as we have previously reported (CohenTannoudji et al. 1995). To verify whether the pattern of myometrial PLC $\beta$ expression correlates with that of $\mathrm{Gq} \alpha$ protein, we therefore extended our immunodetection analysis of PLC $\beta$ isozymes to different days of pregnancy. Since PLC $\beta 1$ and PLC $\beta 3$ are highly enriched in the cytosolic compartment of pregnant and term rat myometrium (Mhaouty-Kodja et al. 2004) all the subsequent studies focused on the cytosolic expression of both enzymes.

By using specific antibodies, we detected $150 \mathrm{kDa}$ signals corresponding to PLC $\beta 1$ and PLC $\beta 3$ in pregnant and term rat myometrium as previously reported (Mhaouty-Kodja et al. 2004). Figure 4 shows that the level of both proteins was very low on days 12 and 15 of pregnancy and increased by $300 \%$ at term $(P<0 \cdot 05)$. An interesting finding was that the up-regulation of PLC $\beta 1$ and PLC $\beta 3$ was maximal from day 21 of pregnancy (Fig. 4). It thus appears that, as for many contraction-associated proteins, the up-regulation of PLC $\beta$ isozymes takes place before term, during uterine preparation to labour. Since this period is characterized by important changes in the steroid hormone environment, we assessed whether progesterone and/or oestradiol modulate the expression of rat myometrial PLC $\beta 1$ and PLC $\beta 3$. 
(a)

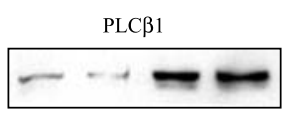

(b)

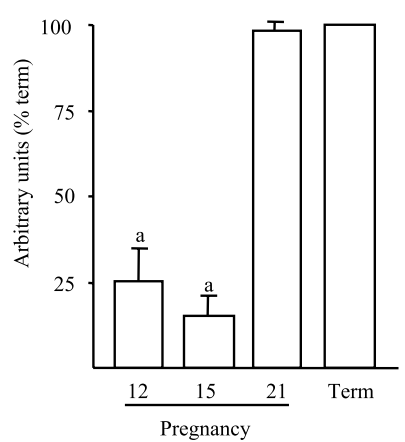

(c)

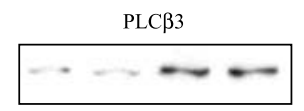

(d)

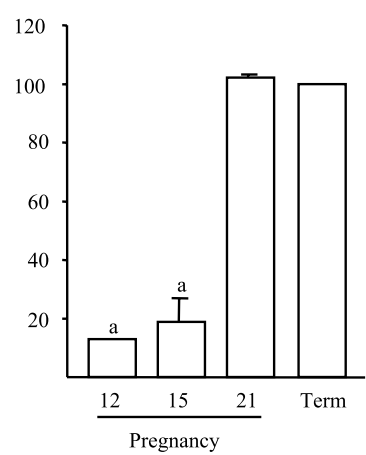

Figure 4 Quantification of amounts of rat myometrial PLC $\beta 1$ and PLC $\beta 3$. $(a$ and $c$ ) Representative Western blots for 150 kDa PLC $\beta 1$ and PLC $\beta 3$ on days 12,15 and 21 of pregnancy and at term. (b and d) Quantitative data are expressed as percent of term. Values are means \pm S.E.M. of three to four independent experiments. ${ }^{a} P<0.05$ versus term or day 21 of pregnancy.

The effects of progesterone and oestradiol on rat myometrial $P L C \beta 1$ and PLC $\beta 3$ expression

To determine whether sex steroids regulate the expression of rat myometrial PLC $\beta 1$ and PLC $\beta 3$, pregnant rats received subcutaneous injections of progesterone or oestradiol. The days of steroid administration were chosen on the basis of our previous studies where myometrial concentrations of progesterone and oestradiol were determined during the course of pregnancy (Elwardy-Mérézak et al. 1994, Cohen-Tannoudji et al. 1995). Progesterone and oestradiol were thus delivered to rats when their myometrial endogenous levels are low, i.e. day 21 of pregnancy for progesterone and day 15 of pregnancy for oestradiol.

Immunoblotting studies illustrated in Fig. 5 show that progesterone failed to alter the level of rat myometial PLC $\beta 1$ and PLC $\beta 3$, which remained similar to that determined on day 21 of pregnancy $(98 \pm 2 \%$ and $107 \pm 18 \%$ of day 21 in progesterone-treated rats for PLC $\beta 1$ and PLC $\beta 3$ respectively). In contrast, oestradiol administration increased the amount of PLC $\beta 1$ to a level similar to that observed on day 21 of pregnancy as shown in Fig. $6 a$ and $b(+260 \%$ above day 15 of pregnancy in oestradiol-treated rats; $P<0 \cdot 05)$. Such treatment also increased the level of PLC $\beta 3(+200 \%$ above day 15 of pregnancy in oestradiol-treated rats; $P<0 \cdot 05$ ) (Fig. $6 c$ and d). In control rats receiving oil, the levels of PLC $\beta 1$ and PLC $\beta 3$ did not change from the values determined on day 15 of pregnancy.

These data revealed, for the first time, that the expression of rat myometrial PLC $\beta 1$ and PLC $\beta 3$ is under the control of oestradiol. The oestradiol-dependent up-

(a)

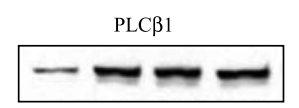

(b)

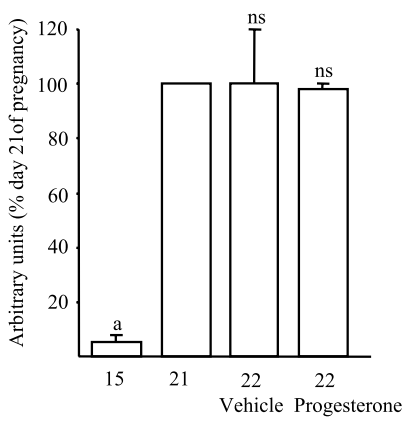

(c)

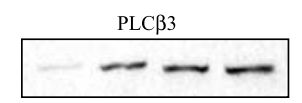

(d)

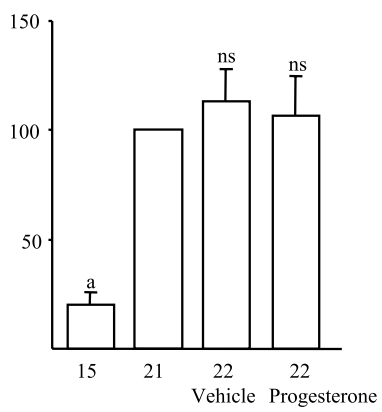

Figure 5 The effect of progesterone on rat myometrial PLC $\beta 1$ and PLC $\beta 3$ expression. ( $a$ and $c)$ Representative Western blots for PLC $\beta 1$ and PLC $\beta 3$ on days 15, 21 or 22 of pregnancy after administration of progesterone or vehicle. ( $b$ and $d$ ) Quantitative data are expressed as percent of day 21 of pregnancy. Values are means \pm S.E.M. of three independent experiments. ${ }^{a} P<0 \cdot 001$ versus day 21 of pregnancy. ns, not significant.

regulation of both enzymes at the end of pregnancy, together with the increased amount of Gqd protein, could underlie the enhanced uterine sensitivity to CCh and OT near term.

\section{Discussion}

The present study reports the first comparison of CChand OT-induced uterine activity and myometrial InsP production between pregnant and term rats. Our results

(a)

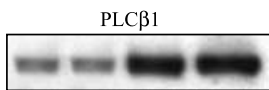

(b)

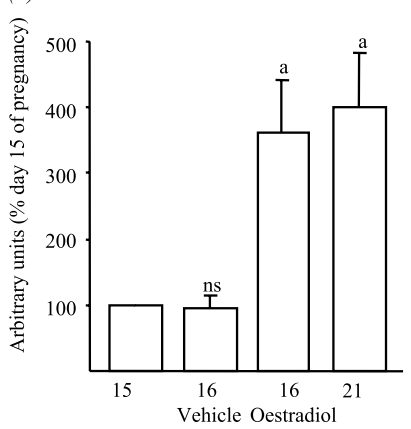

(c)

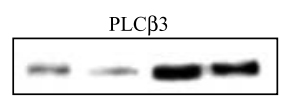

(d)

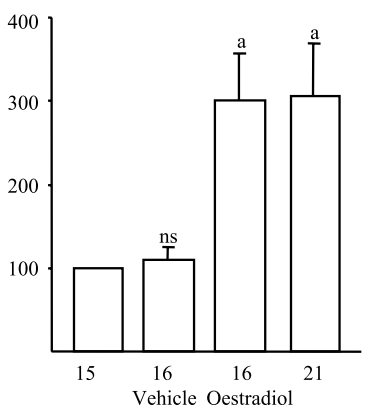

Figure 6 The effect of oestradiol on rat myometrial PLC $\beta 1$ and PLC $\beta 3$ expression. ( $a$ and $c)$ Representative Western blots for PLC $\beta 1$ and PLC $\beta 3$ on days 15, 21 or 16 of pregnancy after administration of oestradiol or vehicle. $(b$ and $d)$ Quantitative data are expressed as percent of day 15 of pregnancy. Values are means \pm S.E.M. of four experiments. ${ }^{\text {a }} P<0.05$ versus day 15 of pregnancy. ns, not significant. 
showed that the potency of $\mathrm{CCh}$ to induce both uterine contraction and InsP production increases at term. At this time, it is interesting to note that the $\mathrm{EC}_{50}$ value calculated for CCh-induced uterine contraction was similar to that reported in cyclic oestrous rats (Houdeau et al. 2003), i.e. following oestrogen impregnation. Furthermore, it was observed that administration of oestradiol to non-pregnant rats resulted in a sharp decrease in the $\mathrm{EC}_{50}$ value for CCh-induced uterine contraction (Abdalla et al. 2004), similar to that observed in our study between pregnancy and term. Because an abrupt increase in plasma and myometrial oestrogen occurred at the onset of parturition, we suggest that the $\mathrm{mR}$ signalling pathway is influenced by changes in the hormonal status between day 15 of pregnancy and term. The higher potency of CCh to increase InsP accumulation and uterine contraction thus occurs when the uterus is under oestrogen dominance. In contrast to a previous report (Lajat et al. 1996), we found no major changes in the ability of $\mathrm{mRs}$ to trigger a maximal InsP production between pregnancy and term. This discrepancy is probably due to the presently observed enhancement $(+72 \%)$ in basal levels of myometrial InsP accumulation at term, which was taken into account in our studies to determine the specific effects of CCh. Moreover, our contraction studies confirmed that no changes in the $\mathrm{E}_{\max }$ for $\mathrm{CCh}$ occur between pregnancy and term. In similar experimental conditions, we found that both uterine sensitivity and maximal response to OT were increased at term, which is in agreement with previous reports (Riemer et al. 1986).

Rat myometrial $\mathrm{M}_{3}$ receptor and OTR are differently sensitive to sex steroids. Indeed, while OTR is downregulated by progesterone during pregnancy and upregulated by oestradiol near term (Larcher et al. 1995), the density of rat myometrial $\mathrm{M}_{3}$ subtype remains unchanged throughout pregnancy (Lajat et al. 1996). Furthermore, neither ovariectomy nor oestradiol treatment affected the density of rat myometrial $\mathrm{M}_{3}$ subtype (Choppin et al. 1999, Abdalla et al. 2004). The increased potency of CCh to induce InsP production and uterine contraction at term is therefore probably related to changes occurring downstream of the $\mathrm{M}_{3}$ receptor, at the level of $\mathrm{G}$ protein and/ or PLC $\beta$ enzymes. In many physiological and cellular models, $M_{3}$ receptor was shown to couple to both PLC $\beta 1$ and PLC $\beta 3$ via activation of the Gqd protein (Kim et al. 1997, Piiper et al. 1997, Strassheim \& Williams 2000). Interestingly, we have recently shown that among the three PLC $\beta$ s (PLC $\beta 1$, PLC $\beta 3$ and PLC $\beta 4$ ) predominantly expressed in pregnant rat myometrium PLC $\beta 4$ is increased at mid-pregnancy while PLC $\beta 1$ and PLC $\beta 3$ are upregulated at term (Mhaouty-Kodja et al. 2004). Furthermore, the pattern of PLC $\beta 1$ and PLC $\beta 3$ expression correlates well with that of their cognate $\mathrm{Gq} \alpha$ protein. Indeed, we have previously reported a $120 \%$ increase in the amount of rat myometrial Gq $\alpha$ protein between day 12 of pregnancy and term (Cohen-Tannoudji et al. 1995). In addition, as for PLC $\beta 1$ and PLC $\beta 3$, the amount of Gq $\alpha$ protein is maximal from day 21 of pregnancy (CohenTannoudji et al. 1995).

From all these data we can conclude that the increased uterine sensitivity to $\mathrm{CCh}$ depends on changes occurring downstream of the $\mathrm{mR}$ while uterine hyperresponsiveness to OT involves up-regulation at both the OTR and post-OTR levels. First, this provides an explanation for the selective increase of the maximal response to OT stimulation at term. Secondly, it suggests that, for a given receptor, amelioration of affinity towards agonists requires an increased availability of $G$ protein and effectors, whereas an enhancement of maximal response requires a further increase of receptor expression level.

The current study provides the first evidence that PLC $\beta 1$ and PLC $\beta 3$ are targets of oestradiol. Indeed, up to date, only corticoids were reported to regulate the expression of PLC $\beta$ enzymes (Dwivedi \& Pandey 1999, Cueille et al. 2003). Furthermore, although oestradiol was suggested to facilitate norepinephrine-, $\mathrm{CCh}-$ and OTinduced PLC activation at a post-receptor level in the myometrium (Riemer et al. 1987, Phaneuf et al. 1995, Abdalla et al. 2000, 2004), no studies have addressed its direct effect on PLC $\beta$ expression. Our findings indicated that administration of oestradiol to rats triggers the expression of myometrial PLC $\beta 1$ and PLC $\beta 3$ to a level normally observed between day 21 of pregnancy and term. This treatment thus anticipates the PLC $\beta 1$ and PLC $\beta 3$ increase that occurs at the end of pregnancy, probably following the enhancement of the oestrogen:progesterone ratio. Our results also indicated that, under our treatment conditions, myometrial PLC $\beta 1$ and PLC $\beta 3$ are insensitive to progesterone. Using a similar protocol, we have previously reported that progesterone significantly reduces the expression of rat myometrial Gqa (Cohen-Tannoudji et al. 1995).

Together, these data add a supplemental step in the regulation of rat myometrial InsP production and thus uterine contraction by sex steroids. It appears then that progesterone and oestradiol not only regulate the expression of receptors like OTR and FP specifically but also act on transduction entities common to different receptors, i.e. Gq $\alpha$ protein and PLC $\beta$ enzymes. During pregnancy, down-regulation of $\mathrm{Gq} \alpha$ by progesterone (CohenTannoudji et al. 1995) associated with low levels of PLC $\beta 1$ and PLC $\beta 3$ (Mhaouty-Kodja et al. 2004, the present study) may participate in the prevention of uterine activation. At term, the increased expression of $\mathrm{Gq} \alpha$ and PLC $\beta 1$ and PLC $\beta 3$ due to progesterone withdrawal and oestrogen increase respectively may underlie the enhancement of uterine responsiveness to uterotonic factors. In myometrium, the expression of many proteins including OTR, connexin-43, cyclo-oxygenase 2 and Gi2 $\alpha$ protein was shown to be regulated at the transcriptional level by oestradiol (Larcher et al. 1995, Lefebvre et al. 1995, Cohen-Tannoudji et al. 1995, Wu et al. 1997). Whether 
or not oestradiol controls the expression of PLC $\beta 1$ and PLC $\beta 3$ at the transcriptional or post-transcriptional level remains to be determined. Analysis of the recently cloned promotor sequence of human PLC $\beta 1$ (Peruzzi et al. 2002) and rat PLC $\beta 3$ (Kang et al. 1997) did not reveal the presence of any known oestrogen-response element. However, it is now clearly established that oestrogens can also control the expression of target genes indirectly through association of their receptors with transcription factors such as Sp1 or AP-1 (Klinge 2001). Interestingly, multiple binding sites for these factors were identified in the $5^{\prime}$-promotor regions of PLC $\beta 1$ and PLC $\beta 3$ (Kang et al. 1997, Peruzzi et al. 2002).

Our contraction studies have shown that the sensitivity of the circular but not the longitudinal muscle to CCh and $\mathrm{OT}$ increases at term. It is of interest that InsP accumulation measured in the whole myometrium also rises at this time, thereby suggesting that the underlying changes in the expression of OTR, Gq $\alpha$, PLC $\beta 1$ and PLC $\beta 3$ occur mainly in the circular muscle. In keeping with this hypothesis, the regulation of OTR by progesterone appears to be restricted to the circular muscle (El Alj et al. 1993). Indeed, this muscle layer contains fivefold less OTR (Kitazawa et al. 2001) and is less sensitive to OT than the longitudinal muscle at mid-pregnancy (MhaoutyKodja et al. 2004). In addition, rat $\alpha 1-A R s$, which are selectively expressed in the circular muscle (Legrand et al. 1991, Mhaouty-Kodja et al. 2004), are also less potent to induce Gqd-mediated PLC activation during pregnancy (Limon-Boulez et al. 1997). We therefore propose that, during pregnancy, progesterone maintains quiescence of the uterine circular muscle through direct downregulation of the PLC signalling molecules (OTR and $\mathrm{Gq} \alpha$ ). In the longitudinal muscle, progesterone might act indirectly on the PLC system through sensitization of the $\beta$-adrenergic signalling pathway (Vivat et al. 1992, Elwardy-Mérézak et al. 1994). Activation of rat $\beta$-ARs, which are selectively localized in this muscle layer (Legrand et al. 1991), significantly decreases myometrial InsP production through both cAMP-dependent and -independent mechanisms (Khac et al. 1996, Dodge et al. 1999, Mhaouty-Kodja et al. 2004). At the end of pregnancy, progesterone withdrawal and the subsequent $\beta$-AR desensitization (Cohen-Tannoudji et al. 1991) probably relieve the PLC system from inhibitory constraints in the longitudinal muscle. Concomitantly, the increase in oestradiol concentrations enhances transcription of the transduction entities involved in the PLC signalling pathway (OTR, PLC $\beta 1$ and PLC $\beta 3$ ) in the circular muscle. Further studies are required to verify this hypothesis in order to enhance our understanding of the regulatory mechanisms underlying the contractile responses of the longitudinal and circular muscles of the uterus.

In summary, we report that the potency of $\mathrm{CCh}$ and $\mathrm{OT}$ to induce rat uterine contraction and myometrial InsP production increases at term. Interestingly, this correlates well with the up-regulation of myometrial PLC $\beta 1$ and PLC $\beta 3$ at this time. This could, together with the previously reported up-regulation of $\mathrm{Gq} \alpha$ protein, participate in switching the rat uterus from a quiescent to an active state. The expression of both PLC $\beta 1$ and PLC $\beta 3$ is under the positive control of oestradiol and seems to be insensitive to progesterone. We also report that changes in uterine responsiveness to $\mathrm{CCh}$ and OT occur mainly in the circular muscle, thereby suggesting differences in the mechanisms underlying the regulation of the PLC system during the course of pregnancy between the longitudinal and circular muscles.

\section{Funding}

The authors declare that there is no conflict of interest that would prejudice the impartiality of this scientific work.

\section{References}

Abdalla FMF, Abreu LC \& Porto CS 2000 Effect of estrogen on intracellular signaling pathways linked to activation of $\mathrm{M}_{2^{-}}$and $\mathrm{M}_{3}$-muscarinic acetylcholine receptors in the rat myometrium. Molecular and Cellular Endocrinology 160 17-24.

Abdalla FMF, Marostica E, Picarelli ZP, Abreu LC, Avellar MCW \& Porto CS 2004 Effect of estrogen on muscarinic acetylcholine receptor expression in rat myometrium. Molecular and Cellular Endocrinology 213 139-148.

Bradford MM 1976 A rapid and sensitive method for the quantitation of microgram quantities of protein utilizing the principle of protein-dye binding. Anaytical Biochemistry 72 248-254.

Choppin A, Stepan GJ, Loury DN, Watson N \& Eglen RM 1999 Characterization of the muscarinic receptor in isolated uterus of sham operated and ovariectomized rats. British Journal of Pharmacology 127 1551-1558.

Cohen-Tannoudji J, Vivat V, Heilmann J, Legrand C \& Maltier JP 1991 Regulation by progesterone of the high-affinity state of myometrial $\beta$-adrenergic receptor and of adenylate cyclase activity in the pregnant rat. Journal of Molecular Endocrinology 6 137-145.

Cohen-Tannoudji J, Mhaouty S, Elwardy-Merezak J, Lecrivain JL, Robin MT, Legrand C \& Maltier JP 1995 Regulation of myometrial Gi2, Gi3, and Gq expression during pregnancy. Effects of progesterone and estradiol. Biology of Reproduction 53 55-64.

Cueille C, Frayon S, de Vernejoul MC \& Garel JM 2003 Dexamethasone decreases phospholipase C $\beta 1$ isozyme expression in human vascular smooth muscle cells. Journal of Steroid Biochemistry and Molecular Biology 86 173-178.

Dodge KL, Carr DW, Yue, C \& Sanborn BM 1999 A role for AKAP (A kinase anchoring protein) scaffolding in the loss of a cyclic adenosine $3^{\prime}, 5^{\prime}$-monophosphate inhibitory response in late pregnant rat myometrium. Molecular Endocrinology 13 1977-1987.

Dwivedi Y \& Pandey GN 1999 Repeated administration of dexamethasone increases phosphoinositide-specific phospholipase C activity and mRNA and protein expression of the phospholipase C $\beta 1$ isozyme in rat brain. Journal of Neurochemistry 73 780-790.

El Alj A, Winer N, Lallaoui H, Delansorne R, Ferre F \& Germain G 1993 Progesterone and mifepristone modify principally the responses of circular myometrium to oxytocin in preparturient rats: comparison with responses to acetylcholine and to calcium. Journal of Pharmacology and Experimental Therapeutics 265 1205-1212.

Elwardy-Mérézak J, Maltier JP, Cohen-Tannoudji J, Lecrivain JL, Vivat V \& Legrand C 1994 Pregnancy-related modifications of rat 
myometrial Gs proteins: ADP ribosylation, immunoreactivity and gene expression studies. Journal of Molecular Endocrinology 13 23-37.

Goureau O, Tanfin Z, Marc S \& Harbon S 1992 Diverse prostaglandin receptors activate distinct signal transduction pathways in rat myometrium. American Journal of Physiology - Cell Physiology 263 C257-C265.

Houdeau E, Rossano B \& Prud'homme MJ 2003 Regional and muscle layer variations in cholinergic nerve control of the rat myometrium during the oestrous cycle. Autonomic Neuroscience 104 1-9.

Kang JS, Lee HB, Rhee SG, Park K \& Yoo OJ 1997 The 5'-upstream region of the rat phospholipase $\mathrm{C}-\beta 3$ gene contains two critical Sp1 sites and an HIV Inr-like element. Gene 197 19-28.

Khac LD, Arnaudeau S, Lepretre N, Mironneau J \& Harbon S 1996 Beta adrenergic receptor activation attenuates the generation of inositol phosphates in the pregnant rat myometrium. Correlation with inhibition of $\mathrm{Ca}^{++}$influx, a cAMP-independent mechanism. Journal of Pharmacology and Experimental Therapeutics 276 130-136.

Kim D, Jun KS, Lee SB, Kang N-G, Mn DS, Kim Y-H, Ryu SH, Suh P-G \& Shin H-S 1997 Phospholipase C isozymes selectively couple to specific neurotransmitter receptors. Nature 389 290-293.

Kitazawa T, Kajiwara T, Kiuchi A, Hatakeyama H \& Taneike T 2001 Muscle layer- and region-dependent distributions of oxytocin receptors in the porcine myometrium. Peptides 22 963-974.

Klinge CM 2001 Estrogen receptor interaction with estrogen response elements. Nucleic Acids Research 29 2905-2919.

Lajat S, Tanfin Z, Guillon G \& Harbon S 1996 Modulation of phospholipase C pathway and level of Gqa/G11 $\alpha$ in rat myometrium during gestation. American Journal of Physiology - Cell Physiology 271 C895-C904.

Larcher A, Neculcea J, Breton C, Arslan A, Rozen F, Russo C \& Zingg HH 1995 Oxytocin receptor gene expression in the rat uterus during pregnancy and the estrus cycle and in response to gonadal steroid treatment. Endocrinology 136 5350-5360.

Lefebvre DL, Piersanti M, Bai XH, Chen ZQ \& Lye SJ 1995 Myometrial transcriptional regulation of the gap junction gene, connexin-43. Reproduction, Fertility and Development 7 603-611.

Legrand C, Vivat V, Rigolot C \& Maltier JP 1991 Selective distribution of alpha-1 and beta adrenoceptors in pregnant rat uterus visualized by autoradiography. Journal of Pharmacology and Experimental Therapeutics 256 767-772.

Limon-Boulez I, Mhaouty-Kodja S, Coudouel N, Benoit de Coignac A, Legrand C \& Maltier JP 1997 The alpha1B-adrenergic receptor subtype activates the phospholipase C signalling pathway in rat myometrium at parturition. Biology of Reproduction 57 1175-1182.

Mhaouty-Kodja S, Houdeau E, Cohen-Tannoudji J \& Legrand C 2001 Catecholamines are not linked to myometrial phospholipase C and uterine contraction in late pregnant and parturient mouse. Journal of Physiology 536 123-131.
Mhaouty-Kodja S, Houdeau E \& Legrand C 2004 Regulation of myometrial phospholipase $\mathrm{C}$ system and uterine contraction by $\beta$-adrenergic receptors in mid-pregnant rat. Biology of Reproduction 70 570-576.

Ou CW, Chen ZQ, Qi S \& Lye SJ 2000 Expression and regulation of the messenger ribonucleic acid encoding the prostaglandin $\mathrm{F}(2$ alpha) receptor in the rat myometrium during pregnancy and labor. American Journal of Obstetrics and Gynecology 182 919-925.

Peruzzi D, Aluigi M, Manzoli L, Billi AM, Di Giorgio FP, Morleo M, Martelli AM \& Cocco L 2002 Molecular characterization of the human PLC $\beta 1$ gene. Biochimica et Biophysica Acta 1584 46-54.

Phaneuf S, Europe-Finner GN, MacKenzie IZ, Watson SP \& Lopez Bernal A 1995 Effects of oestradiol and tamoxifen on oxytocininduced phospholipase C activation in human myometrial cells. Reproduction, Fertility and Development 103 121-126.

Piiper A, Stryjek-Kaminska D, Klengel R \& Zeuzem S 1997 CCK, carbachol and bombesin activate distinct PLC-beta isoenzymes via $\mathrm{Gq} / 11$ in rat pancreatic acinar membranes. American Journal of Physiology - Gastrointestinal and Liver Physiology 272 G135-G140.

Rebecchi MJ \& Pentyala SN 2000 Structure, function, and control of phosphoinositide-specific phospholipase C. Physiological Reviews 80 1291-1335.

Riemer RK, Goldfien AC, Goldfien A \& Roberts JM 1986 Rabbit uterine oxytocin receptors and in vitro contractile response: abrupt changes at term and the role of eicosanoids. Endocrinology 119 699-709.

Riemer RK, Goldfien A \& Roberts JM 1987 Estrogen increases adrenergic- but not cholinergic-mediated production of inositol phosphates in rabbit uterus. Molecular Pharmacology 32 663-668.

Strassheim D \& Williams CL 2000 P2Y2 purinergic and M3 muscarinic acetylcholine receptors activate different phospholipase $\mathrm{C}-\beta$ isoforms that are uniquely susceptible to protein kinase C-dependent phosphorylation and inactivation. Journal of Biological Chemistry 275 39767-39772.

Vivat V, Cohen-Tannoudji J, Revelli JP, Muzzin P, Giacobino JP, Maltier JP \& Legrand C 1992 Progesterone transcriptionally regulates the $\beta_{2}$-adrenergic receptor gene in pregnant rat myometrium. Journal of Biological Chemistry 267 7975-7978.

Wu WX, Ma XH, Zhang Q, Buchwalder L \& Nathanielsz PW 1997 Regulation of prostaglandin endoperoxide $\mathrm{H}$ synthase 1 and 2 by estradiol and progesterone in nonpregnant ovine myometrium and endometrium in vivo. Endocrinology 138 4005-4012.

Received 27 July 2005

Accepted 9 August 2005 